nem in hac terra esse felicem. Constat hunc mundum praeclarum esse". Następnie podany mamy przykład zdania: "Mundum pulchrum esse dicunt" i wyjaśnienie, że Verbum regens bywa tłumaczone nieosobowo - „Mówią, że świat jest piękny", dalej to samo zdanie podane jest w konstrukcji n.c.i., „Mundus pulcher esse dicitur” - Mówi się, że świat jest piękny”. W tej samej lekcji znajdujemy dobre przykłady $\mathrm{z}$ zastosowaniem verba deponentia: „Adoptio naturam imitatur. Dormiunt aliquando leges, numquam moriuntur”. Gerundium w lekcji XXIII (ss. 148-154) znalazło swój wyraz w pięknych między innymi wyrażeniach: „Est tempus nascendi et tempus moriendi, tempus flendi et tempus ridendi, tempus tacendi et tempus loquendi”.

W każdej lekcji spotykamy mnóstwo zwrotów, przysłów i sentencji łacińskich głównie z zakresu prawa i ustawodawstwa rzymskiego. Na stronach 162166 Autorzy wprowadzają nas w arkana kalendarza rzymskiego. Podają łacińskie nazwy miesięcy, dni tygodnia oraz uczą, jak pisać daty w języku łacińskim. Na stronach 167-229 znajdują się następujące działy: a). najczęściej spotykane zwroty i skróty lacińskie (ss. 167-172), np. de domo, de iure, per procura, primo voto; b). indeks przysłów, sentencji i powiedzeń łacińskich (ss. 173-179), np. „Imperare sibi maximum est imperium”; c). indeks sentencji prawniczych (ss. 180-190), np. „Confessio est regina probationum”. „Culpa caret, qui scit, sed prohibere non potest”. „In legibus fundamentum rei publicae”. „Ratio est anima legis”. „Testamentum est iusta sententia de eo, quod quis post mortem suam fieri velit”; d) słownik łacińsko-polski (191-229).

Szata graficzna podręcznika jest bardzo piękna, druk jasny, przejrzysty. W następnym wydaniu może warto podać przy niektórych czasownikach w słowniczku przypadek, którym rządzą np. studeo, studere (dat.) lub careo, carere (abl.). Z podręcznika tego będą korzystali nie tylko studenci prawa, ale także studenci innych kierunków humanistycznych. Może on być także bardzo przydatny w zreformowanym trzyletnim liceum ogólnokształcącym o profilu akademickim. W imieniu ogromnej jeszcze w naszych czasach liczby miłośników języka starożytnych Rzymian i kultury antycznej oraz własnym niech mi wolno będzie przekazać Wielce Szanownym Autorom podręcznika wyrazy głębokiego szacunku i uznania u progu Nowego Stulecia i Tysiąclecia imo ex corde.

Władysław Pokrywka - Starachowice

\title{
Ks. Mariusz SZRAM, Orygenes o kaptaństwie. Antologia tekstów, Hosia- num, Olsztyn 1998, ss. 84.
}

W wydawnictwach teologicznych ostatnich lat temat kapłaństwa pojawia się coraz częściej. Świadczą o tym dosyć liczne nowe publikacje i wznowienia 
prac wielu teologów polskich i zagranicznych. Obok znanych papieskich listów do kapłanów wydawanych co roku z okazji Wielkiego Czwartku należałoby przytoczyć choćby niektóre publikacje książkowe, jak np.: ks. bpa Kazimierza Romaniuka, Nie zaniedbuj w sobie charyzmatu, (Warszawa 1994), Maxa Thuriana, Tożsamość kapłana, (Kraków 1996), Winfrieda Wertmera, Kaptan z powołania, (Częstochowa 1998) czy ks. abpa Józefa Michalika, Przypatrzcie się, bracia, wierze Waszej, (Korczyna 1999). Do wzrostu zainteresowań kapłaństwem przyczyniły się również niewątpliwie wspomnienia Jana Pawła II, Dar i Tajemnica, wydane w 1996 r., z okazji pięćdziesiątej rocznicy święceń kapłańskich. Również wspomnienia kapłanów prześladowanych w systemie władzy komunistycznej, zsyłanych do gułagów, mogły wreszcie ujrzeć światło dzienne, chociaż jeszcze do niedawna tematyka ta stanowiła białą kartę historii i martyrologii duchowieństwa nie tylko polskiego.

Na tle przykładowo tylko nadmienionych publikacji Antologia ks. Mariusza Szrama, adiunkta i wykładowcy greckiej teologii patrystycznej na Katolickim Uniwersytecie Lubelskim, pomimo małej objętości jest również książką godną uwagi. Wypełnia ona w jakimś stopniu lukę, jaką niewątpliwie na rynku polskim stanowi nadal brak większych prac i monografii omawiających kapłaństwo w oparciu o nauczanie Ojców Kościoła. Lukę tę wypełnia w niemałym stopniu 24 tom „Vox Patrum”, zawierający na ten temat aż 24 artykuły (oraz 4 odpowiadające im przekłady) i obszerną bibliografię o kapłaństwie wczesnochrześcijańskim (ss. 499-556), będące materiałami zorganizowanego wcześniej (29-30 X 1991) przez Międzywydziałowy Zakład Badań nad Antykiem Chrześcijańskim KUL ogólnopolskiego sympozjum na temat: „Kapłaństwo w starożytności chrześcijańskiej”. Zakład ten przygotowuje również, jak mi wiadomo, obszerną antologię tekstów o kapłaństwie wczesnochrześcijańskim. Antologia ks. Szrama jest jednak tym bardziej ciekawa, że opiera się na pismach Orygenesa, co w kontekście żywych po dzień dzisiejszy sporów, chociażby odnośnie do święceń kapłańskich tego wielkiego teologa, jest bardzo ważna i interesująca.

Książka podzielona jest na 2 części. W części I (ss. 9-34) ks. Szram dokonuje bardzo wnikliwej analizy nauki autora De principis w odniesieniu do kapłaństwa. Naukę Orygenesa osadza w bardzo ważnym i przejrzystym kontekście historycznym. Otóż gdy aleksandryjski katecheta przebywał w 215 r. w Cezarei, pomimo młodego wieku zachwycił słuchających jego katechezy biskupów, którzy pozwolili mu również na publiczne wyjaśnianie i interpretację Pisma Świętego. Biskup Aleksandrii Demetriusz wezwał młodego teologa do Aleksandrii, dając do zrozumienia w liście skierowanym do biskupów palestyńskich, że jest czymś kuriozalnym, aby osoba świecka nauczała w obecności biskupów i to $\mathrm{w}$ obcej diecezji. Z odpowiedzi dowiadujemy się, że takie przypadki, pewnie nieliczne, miały jednak miejsce (por. s. 10). Same święcenia kapłańskie otrzymał Orygenes w 231 r. na wniosek biskupa Teoktysta z Cezarei i Alek- 
sandra z Jerozolimy. Naruszona więc została jurysdykcja biskupa Demetriusza, ale chyba jeszcze bardziej jego osobista duma. Wprawdzie synod aleksandryjski w 231 r. zakazał Orygenesowi sprawowania urzędu kapłańskiego w Aleksandrii, nie podważył jednak ważności jego święceń. Co do osobistej dyspozycji Orygenesa, nic nie wskazuje na to, iż nie chciał ich przyjąć (s. 11-12). Jedyną nieprawidłowością w przyjęciu święceń był brak zgody aleksandryjskiego ordynariusza.

Również problem samokastracji Orygenesa jest wyjaśniony w tej części pracy. Same wypowiedzi Aleksandryjczyka, jak i skąpa ilość źródeł (głównie Euzebiusz z Cezarei), każą nam z dużą ostrożnością podchodzić do tej kwestii. Także konieczność uniknięcia błędu anachronizmu (kastracja jako przeszkoda do święceń została zdefiniowana dopiero na Soborze Nicejskim!), stawia w zupełnie innym świetle domniemane okaleczenie Orygenesa. Książka ks. Szrama nie stanowi apologii Aleksandryjczyka, ale już sam kontekst historyczny wraz z niejednoznaczną postawą biskupa Demetriusza, stanowią ważne źródło poznania prawdy.

Ważniejszym jednak zagadnieniem, bardzo dogłębnie zanalizowanym przez autora niniejszej pracy, jest sam stosunek Orygenesa do kapłaństwa, wyrażony w jego nauczaniu na temat tego sakramentu. Na podstawie wspomnianych wnikliwych analiz, których wartość jest udokumentowana przez licznie cytowane teksty w języku greckim, jawi się przed nami głęboka teologia kapłaństwa, stanowiąca fundament wielu dzisiejszych refleksji teologicznych. Orygenes daje tu świadectwo głębokiego pragnienia świętości kapłana (s. 19), który będąc nawet grzesznikiem nie traci nieusuwalnego „charakteru” (s. 2021). Aleksandryjski teolog jako jeden $\mathrm{z}$ pierwszych podkreśla, że termin „charakter” oznacza nieusuwalny znak, jaki zostaje wyciśnięty w momencie święceń (tamże).

Nauczanie Aleksandryjczyka w odniesieniu do kapłaństwa dotyka wszystkich jego przejawów. Wielkim walorem książki jest również ukazanie kapłaństwa w kontekście aleksandryjskiej szkoły alegorycznej na potrójnej płaszczyźnie interpretacji biblijnej: literalnej, moralnej i duchowej. Orygenes ukazuje rozwój idei kapłaństwa w Starym Testamencie, jako cienia (umbra), obrazu (imago) Nowego Testamentu i jego rzeczywistości (res) w Liturgii Niebieskiej. Orygenes podkreśla, że tylko Chrystus posiada pełnię kapłaństwa, w którym uczestnictwo mają kapłani na mocy święceń. Ciekawa jest również alegoria Chrystusa - prawdziwego biskupa, patriarchów - prawdziwych prezbiterów, aniołów - prawdziwych diakonów, jako doskonałej hierarchii niebieskiej, której odbiciem jest hierarchia ziemska (s. 26-27).

Wiele uwagi poświęca Aleksandryjczyk także kapłaństwu powszechnemu wszystkich wiernych na mocy chrztu świętego. Mają oni składać na ołtarzu własnej duszy ofiary duchowe, jak: miłość, cierpliwość, modlitwa, pokuta... Godność tego kapłaństwa jest podtrzymywana przez rozważanie Pisma świę- 
tego i zgodne z nim życie (s. 28). Również wiele miejsca poświęca Orygenes kwestiom obowiązków zarówno duchownych, jak i świeckich wobec kapłaństwa urzędowego. Strzeżenie depozytu wiary, głoszenie Słowa Bożego, a nade wszystko osobista świętość to rdzeń nauczania orygenesowskiego (s. 29-34).

Część II (ss. 35-80) książki stanowią teksty, będące ilustracją i potwierdzeniem analiz z części I. Znajdują się tu fragmenty komentarzy i homilii Orygenesa do Księgi Jozuego, Liczb, Sędziów, proroka Jeremiasza, Ezechiela, Pieśni nad Pieśniami, do Ewangelii św. Łukasza, Mateusza, Jana, do listu świętego Pawła do Rzymian, a przede wszystkim do Księgi Kapłańskiej. W antologii zawarte są również teksty z apologii Contra Celsum i traktatu $O$ modlitwie.

Książka księdza Mariusza Szrama - to głębokie spojrzenie na teologię kapłaństwa jednego z największych pisarzy wczesnochrześcijańskich, Orygenesa. Winna się niewątpliwie nie tylko znaleźć na biurkach specjalistów - patrologów, ale przede wszystkim stać się uważną lekturą zarówno kapłanów, jak i świeckich, pragnących odkryć czy pogłębić kapłaństwo powszechne i sakramentalne - niezwykły dar od Chrystusa, Najwyższego Kapłana.

Ks. Sławomir Czalej - Lublin

\section{Bazyli DEGÓRSKI OSPPE, Przekaz tacińskich rękopisów „, Vita Sancti Pau- li primi eremitae" św. Hieronima, Lublin 2000, Międzywydziałowy Zakład Badań nad Antykiem Chrześcijańskim KUL, ss. 450.}

Wspaniała praca o. prof. Bazylego Degórskiego, mnicha zakonu św. Pawła Pustelnika i profesora patrologii Papieskiego Uniwersytetu św. Tomasza z Akwinu w Rzymie - dzieło mogące stać się klasyczną pozycją dla badań źródeł patrystycznych i dla metodologii zbierania, analizy i klasyfikacji rękopisów, oraz dla szeroko pojętych poszukiwań naukowych dotyczących starożytności chrześcijańskiej; ukazało się drukiem wśród publikacji Międzywydziałowego Zakładu Badań nad Antykiem Chrześcijańskim Katolickiego Uniwersytetu Lubelskiego. Jej Autor - rygorystyczny i skrupulatnie dokładny w metodzie klasyfikacji rękopisów - obrał zasadę kolacjonowania wszystkich manuskryptów Vita Sancti Pauli św. Hieronima aż do XI w. włącznie, dodając ponadto niektóre rękopisy napotkane okazjonalnie, a pochodzące z późniejszych wieków.

Hieronimowa Vita S. Pauli należy do tryptyku biografii ascetów (Pawła Tebańskiego, Hilariona i Malchusa), dzięki którym dalmacki Doktor - wspaniały biblista - musi być uznany także za inicjatora łacińskiego piśmiennictwa monastycznego. Owe trzy Vitae jawią się jako historyczni świadkowie tych świętych mnichów i jako literatura budująca z okresu początków monastycyzmu chrześcijańskiego w swojej najbardziej czystej postaci tradycji pustyni 